\title{
TITLE:
}

\section{GASTROPTERON POHNPEI, A NEW GASTROPTERIDAE FROM MICRONESIA (OPISTHOBRANCHIA : CEPHALASPIDEA)}

\section{$\operatorname{AUTHOR}(\mathrm{S}):$}

Hoff, P. J.; Carlson, C. H.

\section{CITATION:}

Hoff, P. J. .... [et al]. GASTROPTERON POHNPEI, A NEW GASTROPTERIDAE FROM

MICRONESIA (OPISTHOBRANCHIA : CEPHALASPIDEA). PUBLICATIONS OF THE SETO MARINE BIOLOGICAL LABORATORY 1983, 27(4-6): 261-264

\section{ISSUE DATE:}

1983-01-31

URL:

http://hdl.handle.net/2433/176055

RIGHT: 


\title{
GASTROPTERON POHNPEI, A NEW GASTROPTERIDAE FROM MICRONESIA (OPISTHOBRANCHIA: CEPHALASPIDEA) ${ }^{1)}$
}

\author{
P.J. HOFF and G.H. CARLSON \\ The Marine Laboratory, University of Guam, Mangilao, Guam 96913
}

With Text-figures $1-3$

While collecting in a sea grass bed on the reef flat near Nahpali, Ponape, 9 specimens of a small gastropterid species were collected from the blades of Enhalus acoroides. To the authors' knowledge this is the first member of the family Gastropteridae to be reported from Ponape.

\section{Gastropteron pohnpei n. sp.}

Specimens were from 1.5 to $2.5 \mathrm{~mm}$ long. The general body shape is that of a member of the family Gastropteridae. The cephalic shield (Text-fig. 1; C. s.) is short, about one quarter of the body length, comparatively flat and generally with a straight anterior margin. On occasion this margin may have a slight medial bulge and at other times be slightly indented. The shield narrows posteriorly forming a funnel (Text-fig. 1; F.) for the projecting dorso-median crest (Text-fig. 1; M. c.). The crest is long, extending well past the funnel and projects forward almost to the anterior limit of the head when seen from a dorsal view. There is a slight furrow in the posterior base of the crest. The eye spots are near the anterior base of the funnel and are not clearly visible except when the head is turned to the side.

The dorsal hump (Text-fig. 1; D. h.) is low, short, rounded, and is distinct from the tail. There are no projections or appendages on the posterior of the hump, however there are some small bumps along the right posterior in some specimens. The mantle margin (Text-fig. 2; M. m.) creates a shoulder anteriorly and extends posteriorly to the end of the ctenidium where it broadens slightly before terminating against the dorsal hump. The ctenidium (Text-fig. 1; G.) is composed of three leaflets (Text-fig. 2; C. 1.). The top two are plicate, somewhat triangulate, curving toward the posterior of the animal and are attached anteriorly just under the mantle margin and are free most of their length. The top leaflet is about one half the length of the second leaflet. The basal leaflet is narrow, submedial, runs laterally along the body the same length as the medial leaflet and is attached its entire length.

1) Contribution No. 170 from the University of Guam Marine Laboratory.

Publ. Seto Mar. Biol. Lab., XXVII (4/6), 261-264, 1983.

(Article 12) 


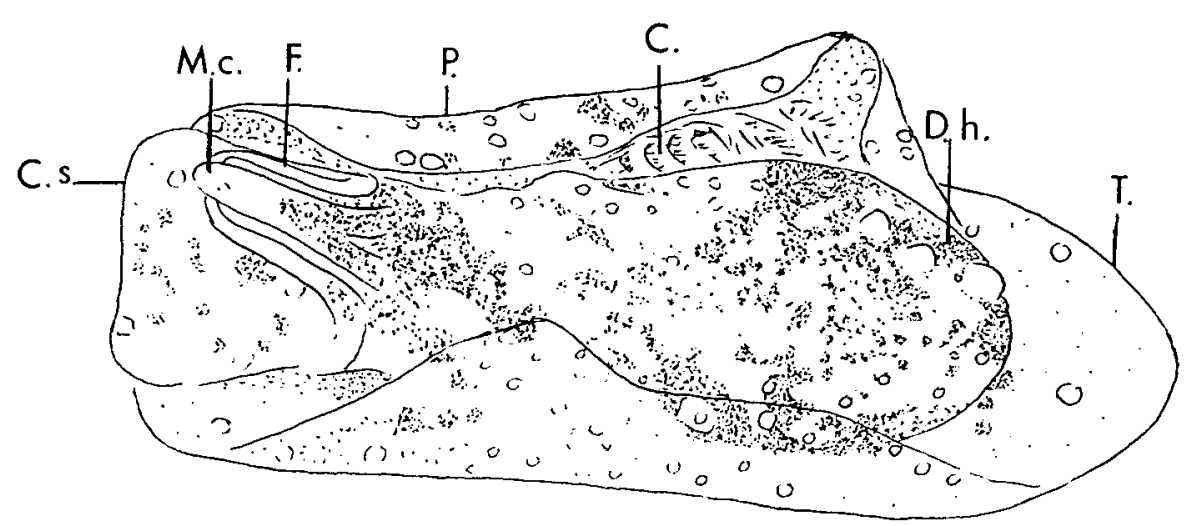

Fig. 1. Gastropteron pohnpei n. sp. Dorsal view of a $3.5 \mathrm{~mm}$ specimen. Dark areas indicates brown markings. Circles indicate cream spots. For abbreviations see page 264.

It is not plicate. Although the ctenidium is usually covered by the parapodia, the posterior of the leaflets can sometimes be seen when the animal is crawling. The anus (Text-fig. 2 ; A.) is posterior to the ctenidium.

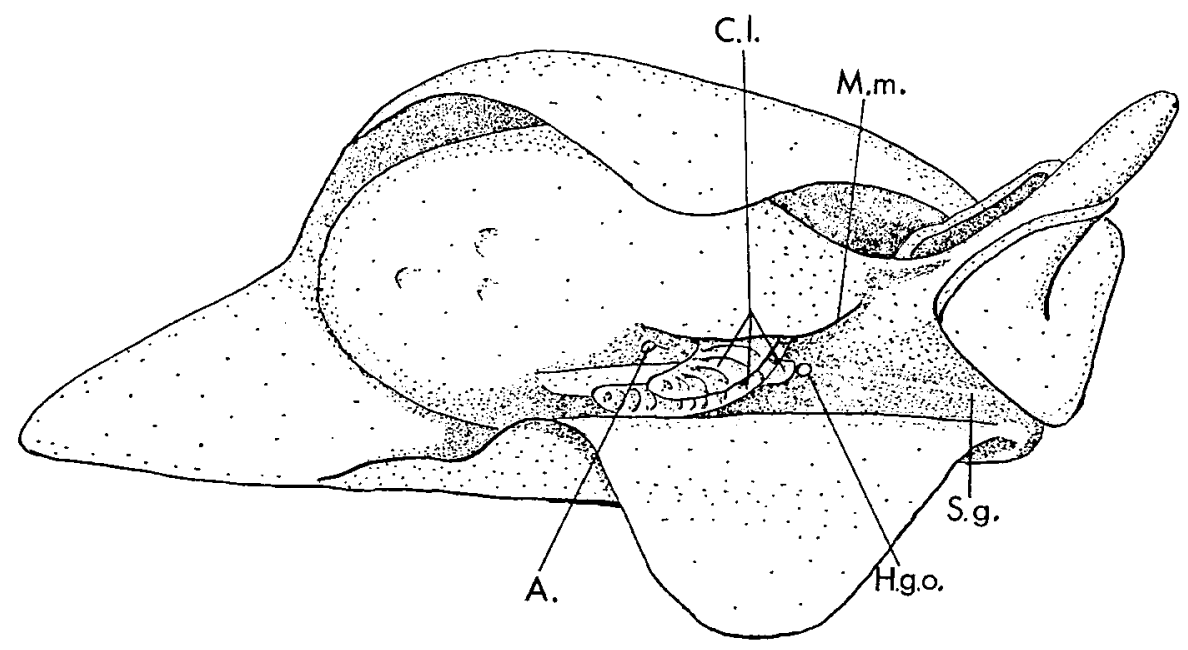

Fig. 2. Gastropteron polinpei n. sp. Right side.

The seminal grove (Text-fig. 2; S. g.) is indistinct in living specimens, obvious in preserved specimens, and runs from the male genital orifice near the mouth to the hermaphroditic genital orifice (Text-fig. 2 ; H. g. o.) just anterior to the medial ctenidial leaflet.

The parapodia (Text-fig. 1; P.) extend from the anterior end of the foot to an area even with the posterior margin of the dorsal hump. On some specimens the parapodia were very high, almost meeting over the dorsum. At times the parapodia were held further from the body and did not extend across the dorsum. The highest part of the parapodia was normally at the anterior of the dorsal hump. The 
parapodia are not distinct from the sole but are distinct from the long rounded tail (Text-fig. 1; T.).

No shell was found in the animals dissected. The radular formulae of two $2.0 \mathrm{~mm}$ specimens were $19 \times 4.1 .0 .1 .4$ and $18 \times 3.1 .0 .1 .3$. The radular ribbon was $350 \mu \mathrm{m}$ long. The first lateral (Text-fig. 3 ; L.) bears 5 to 7 long sharp denticles

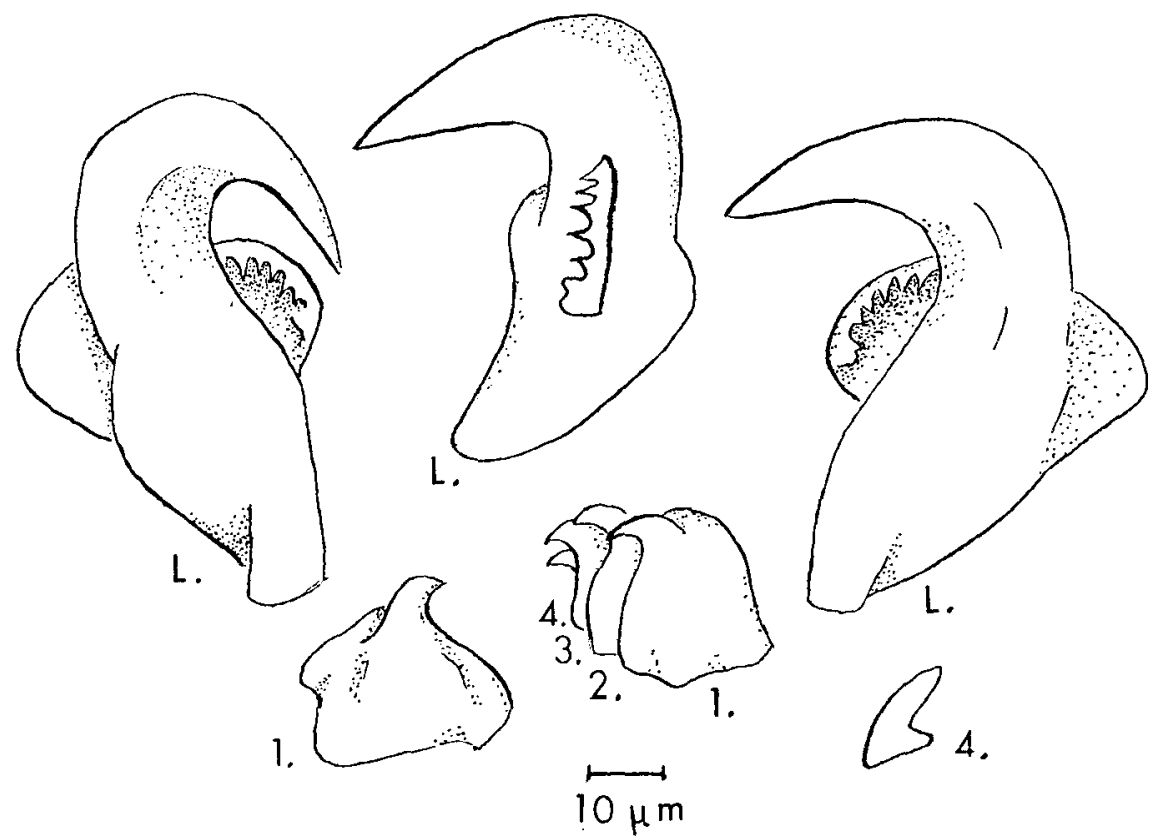

Fig. 3. Gastropteron pohnpei n. sp. Radular teeth.

on a large flange. Below the sharp denticles is a larger thickened, irregular ridge. The marginal teeth (Text-fig. 3; 1, 2, 3, 4) are simple. The first marginal tooth has a high, wide shoulder on the side adjacent to the lateral. A cuticular thickening was noticed where jaw elements would be expected but none were found.

Specimens of Gastropteron pohnpei are transparent with scattered brown flecks on head, parapodia, tail and dorsum (Text-fig. 1). The light tan liver is visible in the dorsal hump. On some specimens the brown flecks may be confluent enough in some areas to cause a mottled appearance; in others it may be almost totally absent. Some cream flecks are found on the dorsal hump and on occasion there is sparce cream flecking over the body and parapodia (Text-fig. 1). Both the brown and cream flecks give the impression of being crystalline. In photographs the cream flecks appear almost yellow. Larger cream spots located on the posterior of the dorsal hump and edges of the parapodia do not have the crystalline appearance. The bumps when present on the dorsum are cream. Preserved animals are tan, the larger animals retaining a few dark brown flecks.

Specimens were difficult to see on the blades of the Enhalus. In many cases they were only noticed because of the tan coloration of the liver against the green 
of the sea grass. The specimens that were returned to Guam alive were placed on some Enhalus in the laboratory but showed no particular affinity for the grass.

Copulation took place in the laboratory with animals taking a head to tail position. In one case, one specimen crawled part way up the right side of another. Three solid gelatinous egg masses were laid in the laboratory. The individual capsules were ovate, measuring about $80 \times 100 \mu \mathrm{m}$.

This species appears to be unique among the already described species of IndoPacific Gastropteridae on the bases of color, number of ctenidial leaflets, number of denticles on the lateral teeth, and habitat. It shares with Gastropteron japonicum (Tokioka \& Baba) and G. bicornutum (Baba \& Tokioka) the large ridge on the flange of the lateral teeth and also shares with $G$. japonicum the absence of any projection on the posterior of the dorsal hump. It shares with $G$. brunneomarginatum (Carlson \& Hoff), G. japonicum, and $G$. bicornutum the plicate, triangulate ctenidial leaflets. $G$. brunneomarginatum has very small, poorly developed ctenidium in comparison with $G$. pohnpei. G. japonicum and $G$. bicornutum have far more ctenidial leaflets than $G$. pohnpei, with 13 and 12 to 18 respectively.

The species name pohnpei is the local name for the island where this species was found.

Type specimens are deposited in the Bernice P. Bishop Museum, Honolulu, Hawaii.

\section{ABBREVIATIONS}

$\begin{array}{ll}\text { A. } & \text { Anus } \\ \text { C. } & \text { Ctenidium } \\ \text { C.l. } & \text { Ctenidial leaflets } \\ \text { G.s. } & \text { Cephalic shield } \\ \text { D.h. } & \text { Dorsal hump } \\ \text { F. } & \text { Funnel } \\ \text { H.g.o. } & \text { Hermaphroditic genital orifice }\end{array}$

$\begin{array}{ll}\text { L. } & \text { Lateral } \\ \text { M.c. } & \text { Dorso-median crest } \\ \text { M.m. } & \text { Free mantle margin } \\ \text { P. } & \text { Parapodia } \\ \text { S.g. } & \text { Seminal groove } \\ \text { T. } & \text { Tail }\end{array}$

\section{REFERENCES}

Baba, K. \& T. Tokioka, 1965. Two more new species of Gastropteron from Japan, with further notes on G. flavum T. \& B. (Gastropoda: Opisthobranchia). Publ. Seto Mar. Biol. Lab., 12 (5): 363378 , text-figs. $1-8$, plate $\mathrm{XXV}$.

Carlson, C.H. \& P.J. Hoff, 1974. The Gastropteridae of Guam, with descriptions of four new species (Opisthobranchia: Cephalaspidea). Publ. Seto Mar. Biol. Lab., 21 (5/6): 345-363, text-figs. $1-13$, plate $\mathrm{X}$.

Tokioka, T. \& K. Baba, 1964. Four new species and a new genus of the family Gastropteridae from Japan (Gastropoda: Opisthobranchia). Publ. Seto Mar. Biol. Lab., 12 (3): 201-229, text-figs. 1-15, plates 10-13.

Note added in proof: The authors have now also found specimens of Gastropteron pohnpei in Palau. 